\title{
HUBUNGAN ANTARA KADAR ASAM URAT SERUM DENGAN TINGKAT KEPARAHAN PENYAKIT JANTUNG KORONER DI RSU PKU MUHAMMADIYAH YOGYAKARTA
}

\author{
Setiasih, U. ${ }^{1}$, Marfianti, E. ${ }^{2}$ \\ ${ }^{1}$ Mahasiswa Pendidikan Dokter Fakultas Kedokteran Universitas Islam Indonesia \\ ${ }^{2}$ Departemen Ilmu Penyakit Dalam Fakultas Kedokteran Universitas Islam Indonesia
}

\begin{abstract}
ABSTRAK
Latar Belakang

Penyakit jantung koroner (PJK) dikenal sebagai penyebab utama kematian. Faktor risiko yang jarang disebutkan yaitu, tingginya kadar asam urat serum. Hubungan yang pasti antara keduanya sebenarnya masih kontroversial dan masih terus diteliti kebenarannya. Beberapa penelitian menyebutkan bahwa asam urat berkorelasi dengan perburukan PJK.

\section{Tujuan}

Tujuan penelitian ini adalah untuk mengetahui hubungan antara kadar asam urat serum dengan tingkat keparahan penyakit jantung koroner di RSU PKU Muhammadiyah Yogyakarta.

\section{Metode}

Desain penelitian adalah cross sectional. Data diambil dengan metode consecutive sampling dari catatan rekam medis pasien PJK periode 1 Januari 2010 - 31 Desember 2012. Subyek penelitian adalah (1) Pasien didiagnosis dokter menderita PJK dengan kriteria PERKI, (2) Kelengkapan rekam medis meliputi nama, umur, jenis kelamin, kadar asam urat, dan tingkat keparahan PJK (kejadian komplikasi). Kadar asam urat yang dipakai adalah kadar asam urat yang pertama kali diukur saat masuk rumah sakit. Tingkat keparahan PJK dibagi kedalam PJK fatal dan non-fatal berdasarkan ada tidaknya komplikasi dan ancaman kematian. Analisis data dilakukan dengan uji Chi Square.
\end{abstract}

\section{Hasil}

Berdasarkan hasil analisis data dengan menggunakan uji Chi Square dari total 68 sampel penelitian $\left(\mathrm{n}_{1}=\mathrm{n}_{2}=34\right)$ diperoleh nilai $\mathrm{p}=0,28$ dengan Rasio Prevalence $=1,643(95 \% \mathrm{CI}=$ $1,033-2,613)$.

\section{Kesimpulan}

Terdapat hubungan antara kadar asam urat serum dengan tingkat keparahan penyakit jantung koroner di RSU PKU Muhammadiyah Yogyakarta.

Kata Kunci: Asam urat, tingkat keparahan, penyakit jantung koroner 


\section{ABSTRACT}

\section{Background}

Coronary heart disease (CHD) is known as the leading cause of death. The high levels of serum uric acid is one of the risk factor which has rarely been assessed. The exact relationship between them is still controversial and it still needs to identify. Some studies suggest that uric acid correlated with CHD fatality.

\section{Objective}

To determine the relationship between serum uric acid levels with severity of coronary heart disease in RSU PKU Muhammadiyah Yogyakarta.

\section{Methods}

The study design was cross-sectional. Data were taken with consecutive sampling on medical record CHD period 1 January 2010 until 31 December 2012. Subjects were (1) CHD patients were diagnosed according to the criteria of PERKI, (2) Completeness of medical records include name, age, gender, uric acid levels (on the first measurement), and severity of CHD (incidence of complications). Severity of CHD were divided to fatal and non-fatal CHD based on the presence of complications and risk of death. Data were analyzed by Chi Square test.

\section{Results}

Chi Square test of 68 total study samples $(n 1=n 2=34)$ showed significant difference levels uric acid in CHD fatality and non fatality $(p=0.028)$. Prevalence Ratio was $1,643(95 \% \mathrm{CI}=1,033$ $-2,613)$.

\section{Conclusion}

There is a relationship between serum uric acid levels with severity of coronary heart disease in RSU PKU Muhammadiyah Yogyakarta.

Keywords: uric acid, severity, coronary heart disease

\section{PENDAHULUAN}

Penyakit jantung koroner (PJK) merupakan salah satu penyakit jantung yang menyebabkan kematian utama di dunia. World Health Organization (WHO) mencatat lebih dari 7,3 juta orang pertahun atau $12 \%$ meninggal akibat PJK di seluruh dunia pada tahun 2004. ${ }^{1}$ Angka ini diperkirakan meningkat. Di Indonesia, data khusus untuk kasus PJK tidak ditemukan namun $43 \%$ penyebab kematian pada usia diatas 55 tahun adalah penyakit gangguan sirkulasi seperti penyakit jantung koroner, hipertensi dan stroke. Kasus PJK semakin sering ditemukan karena pesatnya perubahan gaya hidup. ${ }^{2}$ Hasil Survey Kesehatan Nasional tahun 2013 prevalensi PJK di Indonesia antara 0,5-1,5\%. ${ }^{3}$

Penyempitan (stenosis) atau spasme arteri koroner merupakan penyebab PJK. 
Penyempitan tersebut menimbulkan darah dan akhirnya diekskresi ke ginjal iskemia akibat ketidakseimbangan antara pasok dan kebutuhan. ${ }^{4}$ Terdapat beberapa melalui urin. ${ }^{6}$

Asam urat bisa menyebabkan infark faktor risiko yang meningkatkan PJK, miokard walaupun tidak berkorelasi antara lain faktor risiko lipid, non lipid dan langsung. Kecenderungan asam urat untuk faktor risiko alami. Faktor risiko lipid menyebabkan infark dipengaruhi oleh meliputi kadar kolesterol total, LDL, dan multifaktor seperti umur, tekanan darah, trigliserida dalam darah yang menyebabkan pembentukan plak di arteri koroner. Faktor risiko non lipid terdiri dari hipertensi, diabete melitus, merokok, stress, obesitas dan kurangnya aktifitas. Sedangkan keturunan, jenis kelamin dan usia termasuk kedalam faktor risiko alami. ${ }^{4,5}$

Peningkatan kadar asam urat serum merupakan faktor risiko yang jarang disebutkan. Asam urat merupakan produk akhir metabolisme purin (adenin dan guanin). Metabolisme purin terjadi secara terus menerus didalam tubuh seiring dengan sintesis dan katabolisme DNA dan RNA. Produksi asam urat meningkat setara dengan perputaran sel akibat penguraian dari asam nukleat. Sehingga walaupun asupan purin tidak ada, tubuh akan tetap membentuk asam urat dalam jumlah yang memadai. Produk asam urat akan disintesis terutama di hati dengan reaksi yang dikatalisis oleh enzim xantin oksidase. Asam urat kemudian mengalir melalui berat badan, perokok, dan serum kolesterol. Hiperurisemia diketahui sebagai indikator kelainan metabolik serta memperparah kejadian penyakit jantung koroner. $^{7}$

Hubungan asam urat dengan penyakit kardiovaskular sebenarnya masih kontroversial dan masih terus diteliti kebenarannya. $^{5}$ Sebuah penelitian menyebutkan bahwa kenaikan serum asam urat berkorelasi positif dengan angka kematian akibat penyakit kardiovaskuler pada laki-laki dan wanita ras kulit putih dan hitam. Kematian tersebut sebagian besar disebabkan infark miokard yang diperparah oleh kadar asam urat tinggi. Asam urat menyebabkan akumulasi kristal urat di sekitar aterosklerosis yang sebelumnya telah terbentuk. ${ }^{8}$ Serum asam urat merupakan prediktor kematian yang kuat untuk penyakit kardiovaskuler pada lakilaki usia pertengahan yang tidak dipengaruhi oleh sindrom metabolik atau gout. ${ }^{9}$ Dalam penelitian eksperimental, asam urat merangsang pelepasan kemokin 
monosit chemo-attractant protein-1,25 dan interleukin-1b (IL-1b), interleukin-6 (IL-6), dan tumor necrosis factor-a (TNF-a). Sehingga asam urat mungkin berkontribusi terhadap perkembangan penyakit pembuluh darah manusia dan aterosklerosis melalui jalur pro-inflamasi. ${ }^{10}$

Penelitian lainnya menyebutkan bahwa sebenarnya asam urat merupakan senyawa antioksidan. Asam urat berkontribusi sekitar $60 \%$ terhadap proses pembersihan radikal bebas dalam plasma manusia. ${ }^{6}$ Akan tetapi efek asam urat sebagai antioksidan bisa berubah menjadi prooksidan jika ada ketidakseimbangan dari antioksidan lain. Asam urat dapat meningkatkan oksidasi Low Density Lipoprotein (LDL) yang bisa memperburuk atherosklerosis yang telah terbentuk sebelumnya dengan cara merusak sel endotel vascular. ${ }^{11}$ Penelitian ini bertujuan untuk mengetahui hubungan antara kadar asam urat serum dengan tingkat keparahan penyakit jantung koroner di RSU PKU Muhammadiyah Yogyakarta.

\section{METODE PENELITIAN}

Penelitian ini merupakan penelitian cross sectional dengan sampel adalah pasien rawat inap dengan penyakit jantung koroner (perempuan dan laki-laki) di RSU
PKU Muhammadiyah Yogyakarta periode 1 Januari 2010 - 31 Desember 2012, diambil secara non random sampling dengan tehnik consecutive sampling. Kriteria inklusi adalah pasien didiagnosis dokter menderita PJK dengan kriteria PERKI, kelengkapan rekam medis meliputi nama, umur, jenis kelamin, kadar asam urat, dan tingkat keparahan PJK (kejadian komplikasi). Kriteria eksklusi adalah gagal ginjal konik.

Pasien penyakit jantung koroner adalah pasien yang telah dinyatakan mengalami penyakit jantung koroner atau infark oleh dokter berdasarkan 2 dari 3 kriteria PERKI, yaitu berdasarkan manifestasi klinis berupa perasaan tertekan dan nyeri dada khas infark, elektro kardiografi (EKG) serta peningkatan enzim jantung. Dalam penelitian ini, data tentang penyakit jantung koroner (PJK) diperoleh dari rekam medis.

Asam urat serum adalah jumlah asam urat dalam serum darah, dinyatakan dalam satuan mg/dl yang diperoleh dari standar pemeriksaan laboratorium RS PKU Muhammadiah Yogyakarta dengan metode kolorimetri enzimatik. Kadar asam urat yang dipakai dalam penelitian ini adalah kadar asam urat yang pertama kali diukur saat masuk rumah sakit. Parameter yang 
digunakan adalah normal pada laki-laki 3,2 dari rekam medis. Gagal ginjal dieksklusi $-7,0 \mathrm{mg} / \mathrm{dl}$ dan pada wanita $2,3-6,1 \mathrm{mg} / \mathrm{dl}$. dikarenakan dapat mempengaruhi hasil Dinyatakan tinggi jika asam asam urat pada penelitian yaitu, dapat mempengaruhi laki-laki >7,0mg/dl dan pada wanita kefatalan (komplikasi) PJK.

$>6,1 \mathrm{mg} / \mathrm{dl}$. Data tentang kadar asam urat diperoleh dari rekam medis.

Tingkat keparahan PJK dibagi menjadi PJK fatal dan non-fatal. ${ }^{15}$ Penyakit jantung koroner fatal adalah kondisi PJK berat dan terdapat ancaman kematian disertai komplikasi berupa gagal jantung, edema paru akut, syok kardiogenik, perikarditis, tromboembolus, ruptur miokardium, dan disritmia/aritmia jantung. $^{12}$ Sedangkan penyakit jantung koroner non-fatal adalah PJK yang tidak disertai komplikasi dan tidak mengancam nyawa. Tingkat keparahan PJK ditentukan oleh peneliti berdasarkan ada tidaknya komplikasi pada data rekam medis.

Gagal ginjal kronik adalah penyakit kegagalan ginjal dengan LFG <60 $\mathrm{ml} / \mathrm{mnt} / 1,73 \mathrm{~m}^{2}$ selama lebih dari 3 bulan dengan atau tanpa kerusakan ginjal Penghitungan GFR dengan menggunakan rumus Kockcroft-Gault. Diagnosis ditegakan oleh dokter dan data diperoleh
Analisis data dilakukan dengan menggunakan program SPSS for windows 16 pada taraf kepercayaan 95\%. Analisa data dengan analisa univariat, dilakukan dengan analisis deskriptif untuk melihat karakteristik masing-masing variabel yang diteliti. Analisis bivariat dilakukan dengan menggunakan uji Chi Square (X2) untuk mengetahui hubungan variabel bebas dengan variabel terkait.

\section{HASIL DAN PEMBAHASAN}

Sampel terkumpul sesuai rencana yaitu 68 pasien dengan penyakit jantung koroner. Karakteristik pasien menunjukkan tidak terdapat perbedaan antara variabel penganggu seperti umur, kadar kolesterol, kadar gula darah dan tekanan darah yang juga merupakan faktor risiko panyakit jantung koroner (Tabel 1). 
Tabel 1. Karakteristik -subjek penelitian $(\mathrm{n}=68)$

\begin{tabular}{|c|c|c|c|c|c|}
\hline & \multicolumn{2}{|c|}{ Asam urat normal } & \multicolumn{2}{|c|}{ Asam urat tinggi } & \multirow[t]{2}{*}{$\mathbf{p}$} \\
\hline & Jumlah & Persen (\%) & Jumlah & Persen (\%) & \\
\hline \multicolumn{6}{|l|}{ Jenis kelamin } \\
\hline Laki-laki & 23 & $67.65 \%$ & 25 & $73.53 \%$ & 0,595 \\
\hline Perempuan & 11 & $32.35 \%$ & 9 & $26.47 \%$ & \\
\hline \multicolumn{6}{|l|}{ Usia } \\
\hline$<45$ tahun & 6 & $17.65 \%$ & 2 & $5.89 \%$ & 0,105 \\
\hline$\geq 45$ tahun & 28 & $82.35 \%$ & 32 & $94.11 \%$ & \\
\hline \multicolumn{6}{|l|}{ Kolesterol } \\
\hline$<200 \mathrm{mg} / \mathrm{dl}$ & 21 & $61.76 \%$ & 22 & $64.70 \%$ & 0,801 \\
\hline$\geq 200 \mathrm{mg} / \mathrm{dl}$ & 13 & $38.24 \%$ & 12 & $35.30 \%$ & \\
\hline \multicolumn{6}{|l|}{ Gula darah sewaktu } \\
\hline$<200 \mathrm{mg} / \mathrm{dl}$ & 25 & $73.53 \%$ & 27 & $79.41 \%$ & 0,567 \\
\hline$\geq 200 \mathrm{mg} / \mathrm{dl}$ & 9 & $26.47 \%$ & 7 & $20.59 \%$ & \\
\hline \multicolumn{6}{|l|}{ Tekanan Darah } \\
\hline$<140 / 90 \mathrm{mmHg}$ & 18 & $52.90 \%$ & 15 & $44.10 \%$ & 0,467 \\
\hline$\geq 140 / 90 \mathrm{mmHg}$ & 16 & $47.10 \%$ & 19 & $55.90 \%$ & \\
\hline
\end{tabular}

Tabel 2. Hubungan kadar asam urat serum dengan tingkat keparahan penyakit jantung koroner

\begin{tabular}{|c|c|c|c|c|c|c|c|}
\hline & & \multicolumn{4}{|c|}{ Tingkat keparahan PJK } & \multirow{3}{*}{ Total } & \multirow{3}{*}{$p$} \\
\hline & & \multicolumn{2}{|c|}{ Fatal } & \multicolumn{2}{|c|}{ Nonfatal } & & \\
\hline & & $\mathrm{N}$ & $\%$ & $\mathrm{~N}$ & $\%$ & & \\
\hline Kadar Asam & Normal & 23 & $67,6 \%$ & 11 & $32,4 \%$ & 37 & 0.028 \\
\hline Urat & Tinggi & 14 & $41,2 \% \%$ & 20 & $58,8 \%$ & 31 & \\
\hline
\end{tabular}

Berdasarkan tabel 2 di atas, dapat dilihat karakteristik dan hubungan kadar asam urat serum dengan tingkat keparahan penyakit jantung koroner. Pasien dengan asam urat tinggi disertai tingkat keparahan PJK fatal sebanyak 23 orang $(67,6 \%)$. Sedangkan pasien dengan asam urat tinggi dan PJK non-fatal sebanyak 11 orang $(32,4$ $\%)$. Pada pasien dengan kadar asam urat normal yang menunjukan PJK fatal ada 14 orang $(41,2 \%)$, sedangkan pasien dengan asam urat normal dan PJK non-fatal ada 20 orang $(58,8 \%)$.
Interpretasi dari hasil uji Chi-square test ini menunjukkan nilai $\mathrm{p}=0,028$ $(\mathrm{p}<0,05)$. -Dengan demikian dapat ditarik kesimpulan bahwa terdapat hubungan secara statistik antara kadar asam urat serum dengan tingkat keparahan penyakit jantung koroner.

Nilai ratio prevalence dari hubungan kadar asam urat serum terhadap tingkat keparahan penyakit jantung koroner adalah 1,643 (95\% CI:1,033 - 2,613). Karena nilai ratio prevalence > 1 maka kadar asam urat merupakan faktor risiko 
munculnya kefatalan (komplikasi) PJK. dalam arteri koroner pada studi kasus Jika nilai lower limit dari 95\% CI mencapai angka 1, maka hubungan yang ditemukan bermakna. Pada penelitian ini nilai CI 95\% tersebut menunjukkan hubungan yang bermakna. Jadi dapat disimpulkan bahwa kadar asam urat serum menjadi faktor risiko yang bermakna terhadap tingginya kejadian penyakit jantung koroner fatal.

Asam urat menjadi prediktor yang kuat terhadap kejadian kematian dan kesakitan pada penyakit jantung. ${ }^{16}$ Serum asam urat memiliki hubungan yang positif dengan penyakit jantung baik pada laki-laki dan perempuan. Peningkatan kadar asam urat secara indenpenden dan signifikan terkait dengan risiko kematian oleh karena gangguan kardiovaskular. ${ }^{8}$

Studi eksperimental pada tikus menunjukkan bahwa asam urat mungkin memiliki peran dalam perburukan penyakit jantung dengan merangsang proliferasi sel otot polos pembuluh darah in vitro, mitogen-activated protein kinase, siklooksigenase-2, dan faktor platelet. Asam urat juga mempengaruhi vaskular jantung melalui penghambatan sinyal oksida nitrit. yang dapat mengganggu produksi oksida nitrit secara langsung. ${ }^{14}$

Asam urat serum merupakan faktor risiko independen untuk kehadiran kalsium terkontrol observasional. Dalam sebuah studi menunjukkan bahwa skor kalsium arteri koroner (CAC) merupakan penanda penyakit aterosklerosis dan prediktor tingkat kefatalan penyakit kardiovaskular. ${ }^{17}$ Berbeda dengan penelitian yang dilakukan oleh Waring(2000), selain sebagai proinflamasi ternyata asam urat juga mempunyai manfaat sebagai bahan antioksidan dan berkontribusi $60 \%$ dalam membersihkan radikal bebas pada serum manusia. Asam urat berinteraksi dengan peroxinitrit membentuk nitrit oksida stabil, dengan tujuan untuk menurunkan potensi peroksinitrit dalam menginduksi kerusakan oksidatif. Dengan demikian, asam urat juga berperan untuk melawan stres oksidatif dan memberikan keuntungan pada sistem kardiovaskular. $^{18}$

Penelitian ini masih terdapat beberapa kelemahan diantaranya jumlah sampel yang hanya terbatas pada pasien PJK di RSU PKU Muhammadiyah Yogyakarta. Selain itu, desain penelitian adalah cross sectional sehingga tidak dapat membedakan variabel sebab akibat karena variabel tersebut diukur dalam waktu. Kelemahan lainnya yaitu peneliti belum menemukan sumber yang pasti dalam mengkatagorikan batasan asam urat tinggi 
atau normal sebagai faktor risiko PJK. Data diambil dari data sekunder rekam medis sehingga tidak bisa meneliti lebih dalam, kesalahan dan ketidaklengkapan rekam medis menjadi salah satu kelemahan penelitian ini. Faktor lain yang mungkin mempengaruhi hasil penelitian adalah pemeriksaan kadar asam urat yang hanya sekali dilakukan. Hal ini mungkin belum bisa mencerminkan keadaan asam urat subjek yang sebenarnya.

\section{KESIMPULAN}

Terdapat hubungan antara kadar asam urat serum dengan tingkat keparahan penyakit jantung koroner.

\section{DAFTAR PUSTAKA}

1. Beltrame JF, Dreyer R, Tavella R. Epidemiology of Coronary Artery Disease. in Current Concepts in Epidemiology, Pathophysiology, Diagnostics and Treatment, Gaze D (Ed.) In Tech China. 2012.

2. Djaja S. Analisis Penyebab Kematian Dan Tantangan Yang Dihadapi Penduduk Lanjut Usia Di Indonesia Menurut Riset Kesehatan Dasar 2007. Buletin Penelitian Sistem Kesehatan 2012;15(4):323-330.

3. Badan Penelitian Dan Pengembangan Kesehatan Kementerian Kesehatan. Riset Kesehatan Dasar (Riskesdas) 2013.

4. Kusmana D, Moechtar H, Patofisiologi Penyakit Jantung Koroner. Buku Ajar Kardiologi. Fakultas Kedokteran Universitas Indonesia, Jakarta. 2001.

5. Torpy JA, Writer MA, Burke AE. Coronary Heart Disease Risk Factors. JAMA; 2009;302(21):2388.
6. Johnson RJ, Duk-Hee K, Feig D, Salah K, John K, Susumu W, et al., Is there A Pathogenetic Role For Uric Acid In Hypertension And Cardiovaskular And Renal Desease? Hypertension 2003;41:1183-90.

7. Braunwald E. Heart Disease A Textbook of Kardiovascular Medicine. Vol 2. WB Saunders, Philadelphia. 2011.

8. Fang J, Alderman H. Serum Uric Acid and Cardiovascular Mortality: The NHANES I Epidemiologic Follow-up Study 19711992, JAMA 2000;18:2404-2410.

9. Niskanen K, David E, Kristiina N, Georg A, Hanna ML, Timo A, et al. Uric Acid Level as a Risk Factor for Cardiovascular And All-Cause Mortality in Middle-aged Men. JAMA 2004;164:1546-1551.

10. Ruggiero AC, Alessandro B, Angelo JG, Maggio M, Vishwa D, et al.. Uric Acid And Inflammatory Markers. Eur Heart J 2006;27:1174-1181.

11. Culleton BF, Larson MG, Kannel WB, Levy D. Serum Uric Acid And Risk Cardiovaskular Disease And Death: The Framingham Heart Study. Annual intern medicine 2006;131:7-13.

12. Sylvia AP, Lorraine MW. Patofisiologi Konsep Klinis Proses-Proses Penyakit. Edisi 4. Penerbit Buku Kedokteran EGC, Jakarta.2006.pp.528-556.

13. Braunwald E. Heart Disease: A Textbook Of Kardiovascular Medicine. Vol 2. W.B Saunders Company, Philadelphia.2011

14. Hare M, Richard J. Uric Acid Predicts Clinical Outcomes in Heart Failure : Insights Regarding the Role of Xanthine Oxidase and Uric Acid in Disease Pathophysiology. American Heart Association, Circulation 2003;107:19511953

15. Wilhelmsen L, Koster M, Harmsen $\mathrm{P}$, Lappa G. Differences Between Coronary Disease And Stroke In Insidence, Case Fatality, And Risk Factors, But Fewdifferences In Risk Factors For Fatal And Non Fatal Events. Eur Heart J, 2005;26; 1916-22

16. Strasak, A. Serum Uric Acid and Risk of Cardiovascular Mortality: A Prospective 
Long-Term Study of 83.683 Austrian Men. Clin Chem. 2008;54(2):273-84.

17. Atar AI, Yılmaz OC, Akın K, Selçoki Y, Er O, Eryonucu B. Serum Uric Acid Level Is An Independent Risk Factor For Presence Of Calcium In Coronary Arteries:
An Observational Case-Controlled Study. Anadolu Kardiyol Derg 2012;13(2):13945.

18. Waring WS, Webb DJ, Maxwell SRJ, Uric Acid As A Risk Factor For Cardiovasculer Disease. Q J Med. 2000.93:707-13. 